体力科学, 60 (3): 259 268 (2011)

\title{
地域在住高齢者の握力による移動能力制限の識別
}

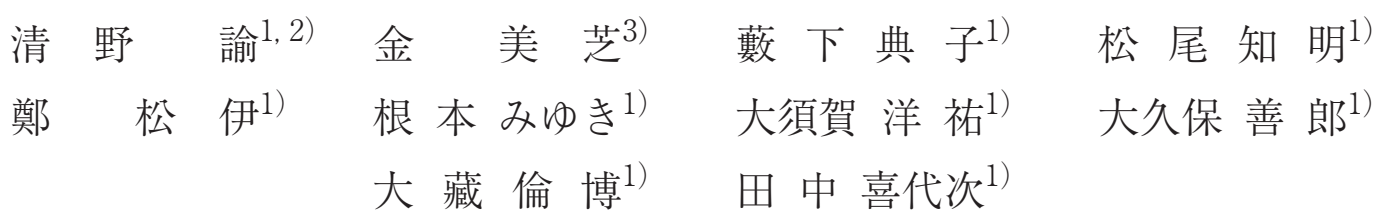

\section{DISCRIMINATION OF MOBILITY LIMITATION BY HAND-GRIP STRENGTH AMONG COMMUNITY-DWELLING OLDER ADULTS}

\author{
Satoshi Seino, Mi-Ji Kim, Noriko Yabushita, Tomoaki Matsuo, \\ Songee Jung, Miyuki Nemoto, Yosuke Osuka, Yoshiro OKubo, \\ TOMOHIRO OKURA and KIYOJI TANAKA
}

(Received January 31, 2011; Accepted February 25, 2011)

\begin{abstract}
The purpose of this study was to determine whether hand-grip strength (HGS) can be a significant discrimination factor of mobility limitation (ML) among older adults. Crosssectional analysis was conducted on data from 939 community-dwelling older adults, aged 6596 years $(74.4 \pm 6.4$ yr, 266 men, 673 women). ML was defined as self-reported difficulty in walking $400 \mathrm{~m}$, climbing 10 steps, and rising from a chair. Trained testers assessed standardized measurements of HGS and lower extremity performance score (LEPS) calculated by four tests (i.e., tandem stance, 5-chair sit-to-stand, alternate step, and timed up \& go). Receiver operating characteristic (ROC) analysis was conducted to identify discrimination power of HGS and LEPS for ML. The areas under the ROC curves (AUCs) of HGS and LEPS for ML were 0.82 and 0.87 in men; 0.70 and 0.85 in women, respectively. No significant difference was detected between the AUCs of HGS and LEPS $(P=0.12)$ in men, whereas in women, the AUC was significantly lower in HGS than LEPS $(P<0.001)$. The optimal HGS cut-off values for ML were $31.0 \mathrm{~kg}$ (sensitivity $75 \%$, specificity $81 \%$ ) for men and $19.6 \mathrm{~kg}$ (sensitivity $73 \%$, specificity $57 \%$ ) for women. In men, the HGS test could be as useful as LEPS for identifying ML. In women, discrimination power for ML by HGS alone was considered acceptable; however, a combination of HGS and lower extremity performance tests could be more useful for monitoring the hierarchical levels of physical frailty.
\end{abstract}

(Jpn. J. Phys. Fitness Sports Med., 60 (3) : 259 268 (2011))

Key words : hand-grip strength, older adults, mobility limitation, ROC curve, AUC

I . 緒

言

高齢者における移動能力の制限（mobility limitation: ML ${ }^{1)}$ は，加齢に伴う障害段階の初期兆候とし て認識されている ${ }^{2)}$. 歩行, 階段昇段, いす立ち上
がり動作に代表される基本的移動能力の低下は，主 観的健康感の悪化 ${ }^{3)}$ 転倒 $^{4)}$, 入院 ${ }^{5)}$, 施設入所 ${ }^{6)}$, 障害 ${ }^{7)}$, 総死亡8) などの危険因子である。したがっ て，これらの一次予防策の1つとして早期にMLを 把握し，適切な支援につなげることが重要となる。
1) 筑波大学大学院人間総合科学研究科 干 305-8577 茨城県つくば市天王台1-1-1

2) 日本学術振興会

干102-8472 東京都千代田区一番町8

3) 東京都健康長寿医療センター研究所 干173-0015 東京都板橋区栄町35-2
Graduate School of Comprehensive Human Sciences, University of Tsukuba 1-1-1 Tennoudai, Tsukuba, Ibaraki, Japan The Japan Society for the Promotion of Science

8 Ichiban-cho, Chiyoda-ku, Tokyo, Japan Tokyo Metropolitan Geriatric Hospital and Institute of Gerontology 35-2 Sakae-cho, Itabashi-ku, Tokyo, Japan 
MLの標準的な評価のあり方として, 歩行や階段昇 段の困難性を問う方法 ${ }^{1)}$ や実際のパフォーマンスか ら評価する方法 ${ }^{5,7)}$ があり，われわれのグループで も，MLを識別可能な下肢パフォーマンス（lower extremity performance: LEP) テストやテストバッ テリに関する検討結果を報告してきている ${ }^{9 \sim 11)}$.

これまで，MLには脚筋力の低下が強く影響する ことが示されてきた ${ }^{12)}$ ，その一方で，握力がこれら を含めた全身の筋力と関連するため ${ }^{13)}$, 握力によっ てMLを把握できる可能性が考えられる。握力測定 の最大の強みは，握る動作のみで測定が可能な簡便 性と, 高い信頼性，安全性である。パフォーマンス テストと健康予後との関連をみたシステマティック レビュー ${ }^{14)}$ においても，握力は最も汎用性の高い フィールドテストであることが示されている。 ま た, 虚弱 ${ }^{15)}$ や健康関連 quality of life ${ }^{16)}$, activities of daily living (ADL) 障害 ${ }^{17)}$, 総死亡 ${ }^{18)}$ など, ML よりもさらに進行した障害段階と関連することから も，握力が初期兆候であるMLを反映できる可能性 は高い.

近年Sallinen et al. ${ }^{19)}$ は, フィンランドの55歳以 上の男女2646名を対象に，握力におけるMLのカッ トオフ值の検討を試みている。その結果，握力が MLを把握するための有用な指標となることが確認 され，男女でそれぞれ $37 \mathrm{~kg}$ （感度：62\%，特異度： 76\%), $21 \mathrm{~kg}$ （感度：67\%, 特異度:73\%）というカッ トオフ值が示されている。 しかし, Sallinen et al. ${ }^{19)}$ は, body mass index (BMI) が $20.0 \mathrm{~kg} / \mathrm{m}^{2}$ 未満の対 象者を除外しており，対象者のBMIおよび握力の平 均值が顕著に高值を示している（男性 : $28.1 \mathrm{~kg} / \mathrm{m}^{2}$, $41 \mathrm{~kg}$; 女性 : $\left.27.6 \mathrm{~kg} / \mathrm{m}^{2}, 23 \mathrm{~kg}\right)$ 。また，欧米の握 力測定では，时関節を $90 \sim 110^{\circ}$ に屈曲させた座位肘 屈曲姿勢での測定が主流であるのに対し ${ }^{18 \sim 20)}$ ，本 邦では立位で持ち手を体側に下げた姿勢（立位肘伸 展姿勢）での測定が通例である。渡邊ら ${ }^{21)}$ はこの姿 勢の違いによって握力測定值が異なることを示して おり，これらの差異が本邦地域在住高齢者における カットオフ值の外的妥当性を低下させる要因の 1 つ と考えられる。ささらに，健康支援現場で活用するに 当たっては，MLに対してすでに妥当性が確認され ているLEPテスト ${ }^{10)}$ と比較して, 握力がどの程度の MLの識別能を有しているかを明らかにすることが 必要である。
そこで本研究の目的は，LEPテストとの比較か ら握力による高齢者の MLの識別力を検討すること とし，十分な識別力が確認できた場合は，MLに対 する握力の基準值をあわせて提案することとした． 現在本邦で展開されている健康支援事業では，ML に関する項目の聴取はしていなくとも，握力を測定 しているケースは極めて多い，握力のみでLEPテ ストと同等にMLを識別できれば，これまで握力と の関連が示されている種々の健康関連情報に加え， MLに関する情報のフィードバックも可能となる. 握力の疫学的指標としての有用性もさらに高まると 考えられる。

\section{II. 方法}

\section{A. 対象者}

本研究では, 65～96歳の地域在住高齢者1043名 (男 性307名，女性736名）を対象とした。対象者はす心゙ て2006〜2010年の間に茨城県, 千葉県, 福島県内の 公民館や保健センター，デイサービスセンターで開 催された体力測定会, 地域支援事業に参加した地域 住民であり，各自治体の広報誌や募集チラシ，自治 体職員による参加推奨などを通して本人の意思で参 加した，対象者のうち，1）体力測定および質問紙 調査の教示を理解できなかった者（12名），2）体 力測定前の問診において脳血管疾患やパーキンソン 病、リウマチなどの神経性疾患の既往があった者 (77名)，３）デー夕に欠損のあった者（15名）を除 外し, 最終的に939名 $(74.4 \pm 6.4$ 歳, 男性 : 266 名, $73.7 \pm 6.4$ 歳, 女性：673名, $74.8 \pm 6.5$ 歳）を解析 の対象とした。すべての対象者に研究の目的や体力 測定および質問紙調査内容を説明し，随時，測定を 拒否できることを確認した。研究での測定デー夕使 用に関する説明を個別に口頭でおこない，書面にて デー夕使用の同意を得た。本研究は，筑波大学に州 属する倫理委員会の承認を受けた。

\section{B. 測定項目および測定方法}

1。基本情報および健康関連情報

性，年齢，および服薬，疾患，関節痛の状況を個 別に聴取した。薬は，医師から処方された医療用医 薬品とし, 薬局等で購入した一般用医薬品や医薬部 外品, サプリメントは除外して数を確認した。疾患 は，高血圧，糖尿病，腎疾患，心疾患（不整脈，心 
不全, 虚血性心疾患など), 呼吸器疾患, 骨粗鬆症, 脂質異常症，関節症の有無（有：1，無：0）をそれ ぞれ確認し, 単純合計した。関節痛は, 肩関節痛, 腰痛，膝関節痛の有無（有：1，無：0）をそれぞれ 確認し，単純合計した。

形態指標として，身長計（YG-200，ヤガミ社製） を用いて $0.1 \mathrm{~cm}$ 単位で身長を, 体重計（Digital Bathroom Scale HD-316, TANITA社製) を用いて0.1kg 単位で体重を測定した。また, 体重 $(\mathrm{kg})$ を身長 $(\mathrm{m})$ の 2 乗で除すことにより BMI を算出した。

自己報告による身体機能の評価として， Medical Outcomes Study 36-item Short Form Survey日本 語版 ${ }^{22)}$ のphysical function scaleを用いた。移動能 力や日常的な身体動作に関連する10の質問項目に対 して，とてもむずかしい（0 点），少しむずかしい ( 5 点)，全然むずかしくない（10点）の 3 件法によ り回答を求め, その合計を 100 点満点で得点化した。

\section{2 . 移動能力制限 (mobility limitation: ML)}

MLの評価に，自己報告による階段昇段，歩行の 困難性 11,12$)$ とともに，いすからの立ち上がりの困難 性を用いた。これら 3 つの生活課題は，本邦の地域 支援事業に拈いて二次予防事業の対象者を把握する ための項目としても用いられている。 それぞれ「手 すりや壁をつたわらずに階段を続けて10段昇ること ができますか」，「休まずに400mを続けて歩くこと ができますか」，「いすに座った状態から何もつかま らずに立ち上がることができますか」の質問に対し て，「十分できる」，「少しむずかしい」，「全然でき ない」の 3 件法で回答を求め, 1 項目でも「少しむ ずかしい」か「全然できない」がある場合をMLあ りとした10,12)

\section{3. 体力測定}

握力によるMLの識別力を検討するに当たり，比 較対照としてLEPの総合指標 ${ }^{11)}$ を用いることとし た。この指標 ${ }^{11)}$ はタンデムバランス，5 回いす立ち 上がり，ステップテスト，タイムドアップ\&ゴーの 4 項目によって構成されており，各測定值を第一主 成分得点の推定式に代入することによって，標準正 規曲線（平均 0 , 標準偏差 1 ）で表わされる総合得 点を算出することが可能である ${ }^{23)}$ 。本研究ではこ の得点をLEP得点 (lower extremity performance score: LEPS）として用いた。 LEPSは，以下の式に よって算出した ${ }^{11)}$.
LEPS $=0.031 \times$ タンデムバランス $-0.106 \times 5$ 回 いす立ち上がり $-0.192 \times$ ステップテスト $-0.096 \times$ タイムドアップ\&ゴー+ 1.672

タンデムバランス，5回いす立ち上がり，ステッ プテスト，タイムドアップ\&ゴーの ML識別に対す

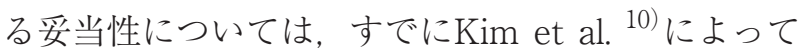
詳細に検討されている，各項目の測定方法は下記の とおりである。

1) 握力

スメドレー式握力計 (GRIP-D, T.K.K5401, 竹井 機器工業社製）を手に持ち，両腕を体側で自然に下 げ，リラックスした姿勢をとるよう求めた。握り幅 は対象者が握りやすいよう調整し，持ち手は身体に 触れないように，かつ動かさないように教示した。 次に，呼息しながら握力計を可能な限り強く握るよ う教示した。 $0.1 \mathrm{~kg}$ 単位で左右交互に 2 回ずつ計測 し，平均值を記録とした。級内相関係数（intraclass correlation coefficient: ICC) による握力の信頼性は 0.98であり，極めて良好な值であった。

2) タンデムバランス

両手を腰に当てて片足を一足分前に出し，前足の かかとと後ろ足のつま先をつけて直線上に立った状 態で，可能な限り長く立ち続けるよう教示した。両 足に均等に体重をかけることとし，足の裏が動いた り，腰に当てた手が離れたり，下肢のみで姿勢の維 持が不可能になった時点でバランスが崩れたものと みなした，計測は，前足のかかとと後ろ足のつま先 をつけて直線上に立った時点からバランスが崩れた 時点までの時間とした，左右の足を入れ替えて 1 回 ずつ0.01秒単位で最大 30 秒まで計測し，平均值を記 録とした。ICCは0.79であり，良好な值であった。

3）5回いす立ち上がり

両腕を胸の前で交差し，背中を伸ばした状態で背 もたれのついたいすに浅く腰かけるよう求めた。合 図とともに，いすから立ち上がり直立姿勢をとり， 再びいすに腰掛ける動作を可能な限り速く 5 回繰り 返すよう教示した。合図してから 5 回目の直立姿勢 をとるまでの時間を0.01秒単位で 2 回計測し，平均 值を記録とした。ICCは0.96であり，極めて良好な 值であった

4) ステップテスト

立位姿勢をとるよう求め，その $20 \mathrm{~cm}$ 前方に $19 \mathrm{~cm}$ の高さの台を設置した，足の裏が台の高さ $(19 \mathrm{~cm})$ 
まで上がるよう，可能な限り速くその場で足踏みを おこなうよう教示し，左右の足を交互に 8 回上げ下 ろしするまでの時間を計測した。測定は 0.01 秒単位 で 2 回計測し，平均值を記録とした。ICCは0.96で あり，極めて良好な值であった。

5 ）タイムドアップ\&ゴー

いすに深い座位姿勢をとり，両手を膝の上に置く よう教示した．合図とともに立ち上がり， $3 \mathrm{~m}$ 前方 のコーンを回って着座するまでの時間を0.01秒単位 で 2 回計測し，平均值を記録とした。一連の動作は 可能な限り速くおこなうよう教示したＩCCは0.99 であり，極めて良好な值であった。

測定の際は，問診によって当日の体調を確認する とともに，体力測定に精通したスタッフが安全性に 十分に留意した。また，測定で補助や支えを必要と した場合はその旨を記録した。

\section{C. 統計解析}

すべての測定項目は，平均值 \pm 標準偏差または 割合（\%）で示し，男女別に解析した，MLなし （Non-ML群）とMLあり（ML群）の健康関連情報, 形態指標，体力測定值の比較には，対応のない $t$ 検 定およびMann-WhitneyのU検定を適用した。体 力測定において補助や支えを必要とした者の割合 は， $x^{2}$ 検定によって比較した。

握力と LEPSにおける MLの識別力の判断基準に は, receiver operating characteristic (ROC) 曲線 を描くことによって得られるROC曲線下面積（area under the ROC curve: AUC) とその95\%信頼区間 （95\% confidence interval：95\% CI）を用いた。握 力と LEPSの識別力を比較するため, 両者の AUC

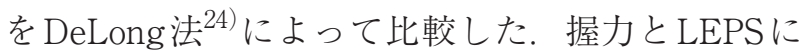
おけるMLの最適なカットオフ值は, ROC曲線上 で最も左上（1-特異度 $=0$, 感度 $=1)$ に近いポ イントとし， $(1-\text { 感度 })^{2}+(1-\text { 特異度 })^{2}$ が最小 になる值を求めた ${ }^{25)}$ 。また, Youden index ${ }^{25)}$ を算 出し，この值が最大になるポイントからも最適な カットオフ值を確認した

握力およびLEPSがカットオフ值を下回った場 合の MLへの該当可能性を検討するため, MLの有 無（有：1，無：0） を従属変数, カットオフ值に 対する測定值の高低（カットオフ值未満：1，カッ トオフ值以上：０）を独立変数としたロジスティッ
ク回帰分析によってオッズ比（Odds ratio: OR）と 95\% CIを算出した。

DeLong法による握力とLEPSのAUCの比較には エクセル用統計解析ソフト Analyse-Itを，その他 のすべての統計処理には統計解析ソフトPASW Statistics 18.0を用い，統計的有意水準はすべて $5 \%$ とした

\section{III. 結果}

Table 1に，すべての測定值と，体力測定で補 助や支えを必要とした者の割合を男女別に示した。 ML群は男性で67名（25\%)，女性で305名（45\%) であった，ML群では，男女とも年齢，疾患数，関 節痛数が有意に高值を示し，身長，体重，physical function scale, 握力, LEPSが有意に低值を示した。 握力測定ではすべての対象者が補助を必要としな かったが，LEPS測定では男女あわせて89名（9.5\%) に壁や杖など何らかの補助が必要であった。LEPS 測定の際に補助や支えを必要とした者の割合は男女 とも ML群で有意に高かった。

Fig 1 には, MLの有無に対する握力とLEPSの ROC曲線を男女別に示した。男性では，握力と LEPSのAUCはそれぞれ0.82 (95\% CI: 0.76-0.88), 0.87 (95\% CI: 0.81-0.93）であり，両者に有意差は みられなかった $(P=0.12$, 差の $95 \%$ CI: $-0.11-$ 0.01)。女性では, 握力とLEPSのAUCはそれぞれ0.70 (95\% CI: 0.66-0.74)， 0.85 (95\% CI: 0.82-0.88） であ り, 握力の AUCがLEPSのAUCよりも有意に低值 を示した $(P<0.001$, 差の95\% CI: $-0.19--0.11)$.

Table 2 には，握力とLEPSにおけるMLの最適 なカットオフ值を男女別に示した。それぞれ男性 では31.0kg（感度：75\%, 特異度：81\%), 0.20 （感 度：81\%, 特異度：84\%), 女性では19.6kg（感度： $73 \%$, 特異度 : $57 \%$ ), -0.01 (感度 : $81 \%$, 特異度： 77\%）であった。

Table 3 に，握力およびLEPSがカットオフ值を下 回った場合の MLに対するORと95\% CIを示した。 男性では，年齢調整後も握力，LEPSともにMLに極 めて強い関連度を示した。女性では, LEPSはML に極めて強い関連度を示したものの，握力はLEPS や男性の握力に比べて弱い関連度を示した。 
Table 1. Characteristics of the study population, mean $\pm \mathrm{SD}$ or $\mathrm{n}(\%)$

\begin{tabular}{|c|c|c|c|c|c|c|}
\hline \multirow[b]{2}{*}{ Characteristics } & \multicolumn{3}{|c|}{ Men } & \multicolumn{3}{|c|}{ Women } \\
\hline & $\begin{array}{c}\text { Overall } \\
(\mathrm{n}=266)\end{array}$ & $\begin{array}{l}\text { Non-ML } \\
(\mathrm{n}=199)\end{array}$ & $\begin{array}{c}\text { ML } \\
(n=67)\end{array}$ & $\begin{array}{c}\text { Overall } \\
(\mathrm{n}=673)\end{array}$ & $\begin{array}{l}\text { Non-ML } \\
(\mathrm{n}=368)\end{array}$ & $\begin{array}{c}\text { ML } \\
(\mathrm{n}=305)\end{array}$ \\
\hline Age, yr & $73.7 \pm 6.4$ & $72.2 \pm 5.4$ & $78.1 \pm 6.9 *$ & $74.8 \pm 6.5$ & $72.4 \pm 5.4$ & $77.6 \pm 6.6 *$ \\
\hline Height, cm & $160.4 \pm 6.7$ & $161.4 \pm 6.4$ & $157.4 \pm 6.6 *$ & $146.7 \pm 6.2$ & $148.5 \pm 5.2$ & $144.6 \pm 6.6 *$ \\
\hline Weight, kg & $60.9 \pm 9.1$ & $61.7 \pm 8.5$ & $58.6 \pm 10.7^{*}$ & $50.9 \pm 8.1$ & $51.0 \pm 7.7$ & $50.8 \pm 8.6 *$ \\
\hline BMI, $\mathrm{kg} / \mathrm{m}^{2}$ & $23.6 \pm 3.1$ & $23.6 \pm 2.9$ & $23.6 \pm 3.7$ & $23.7 \pm 3.5$ & $23.1 \pm 3.1$ & $24.3 \pm 3.8$ \\
\hline No. of diseases & $1.0 \pm 0.9$ & $0.9 \pm 0.9$ & $1.4 \pm 0.9 *$ & $1.3 \pm 1.1$ & $1.0 \pm 1.0$ & $1.6 \pm 1.1 *$ \\
\hline Joint pain, sum & $0.6 \pm 0.7$ & $0.5 \pm 0.7$ & $0.9 \pm 0.8 *$ & $0.8 \pm 0.8$ & $0.6 \pm 0.8$ & $1.0 \pm 0.8 *$ \\
\hline Physical function scale, point (SF-36, 0-100) & $85.0 \pm 17.4$ & $90.9 \pm 10.8$ & $66.1 \pm 20.7^{*}$ & $73.7 \pm 23.0$ & $86.9 \pm 12.8$ & $57.5 \pm 22.4^{*}$ \\
\hline Hand-grip strength, kg & $32.2 \pm 7.5$ & $34.4 \pm 5.9$ & $25.6 \pm 7.7 *$ & $20.5 \pm 4.7$ & $22.1 \pm 4.1$ & $18.7 \pm 4.8 *$ \\
\hline LEPS, point & $0.11 \pm 1.03$ & $0.45 \pm 0.47$ & $-0.93 \pm 1.49 *$ & $-0.17 \pm 1.04$ & $0.32 \pm 0.53$ & $-0.81 \pm 1.18^{*}$ \\
\hline + Tandem stance, $\mathrm{s}$ & $26.9 \pm 7.1$ & $28.6 \pm 4.8$ & $21.7 \pm 10.2^{*}$ & $25.2 \pm 8.2$ & $27.5 \pm 5.9$ & $22.3 \pm 9.7 *$ \\
\hline -5-chair sit-to-stand, $\mathrm{s}$ & $7.9 \pm 3.6$ & $7.0 \pm 1.5$ & $10.7 \pm 5.8 *$ & $8.6 \pm 3.6$ & $7.0 \pm 1.9$ & $10.6 \pm 4.3 *$ \\
\hline - Alternate step, s & $4.7 \pm 1.8$ & $4.2 \pm 0.9$ & $6.4 \pm 2.6 *$ & $5.1 \pm 1.7$ & $4.4 \pm 0.8$ & $6.1 \pm 2.1 *$ \\
\hline - Timed up \& go, $\mathrm{s}$ & $7.0 \pm 3.5$ & $5.9 \pm 1.2$ & $10.3 \pm 5.6 *$ & $8.2 \pm 4.5$ & $6.4 \pm 1.7$ & $10.4 \pm 5.7^{*}$ \\
\hline \multicolumn{7}{|l|}{ Number of participants who needed any assistance } \\
\hline Hand-grip strength, n (\%) & $0(0)$ & $0(0)$ & $0(0)$ & $0(0)$ & $0(0)$ & $0(0)$ \\
\hline LEPS, n (\%) & $20(7.5)$ & $4(2.0)$ & $16(23.9) *$ & $69(10.3)$ & $7(1.9)$ & $62(20.3) *$ \\
\hline + Tandem stance, n (\%) & $4(1.5)$ & $1(0.5)$ & $3(4.5)$ & 21 & $1(0.3)$ & $20(6.6) *$ \\
\hline -5-chair sit-to-stand, n (\%) & $6(2.3)$ & $1(0.5)$ & $5(7.5) *$ & $25 \quad(3.7)$ & $1(0.3)$ & $24(7.9) *$ \\
\hline - Alternate step, n (\%) & $13(4.9)$ & $0(0)$ & $13(19.7) *$ & $47 \quad(7.0)$ & $5(1.4)$ & $42(13.8) *$ \\
\hline - Timed up \& go, n (\%) & $5(1.9)$ & $0(0)$ & $5(7.5) *$ & $20(3.0)$ & $1(0.3)$ & $19(6.2) *$ \\
\hline
\end{tabular}

Notes: $\mathrm{SD}=$ standard deviation; $\mathrm{ML}=$ mobility limitation; $\mathrm{BMI}=$ body mass index

LEPS $=$ lower extremity performance score: $0.031 \times$ tandem stance $-0.106 \times 5$-chair sit-to-stand $-0.192 \times$ alternate step $-0.096 \times$ timed up \& go +1.672

No. of diseases: the sum of hypertension, diabetes mellitus, kidney disease, heart disease, breathing difficulties, osteoporosis, dyslipidemia, arthritis, resulting in a score from 0 to 8

Joint pain: the sum of shoulder pain, low bac pain, knee pain, resulting in a score from 0 to 3

+: Higher values signify better performance, -: Lower values signify better performance

* $P<0.05$ vs Non-ML
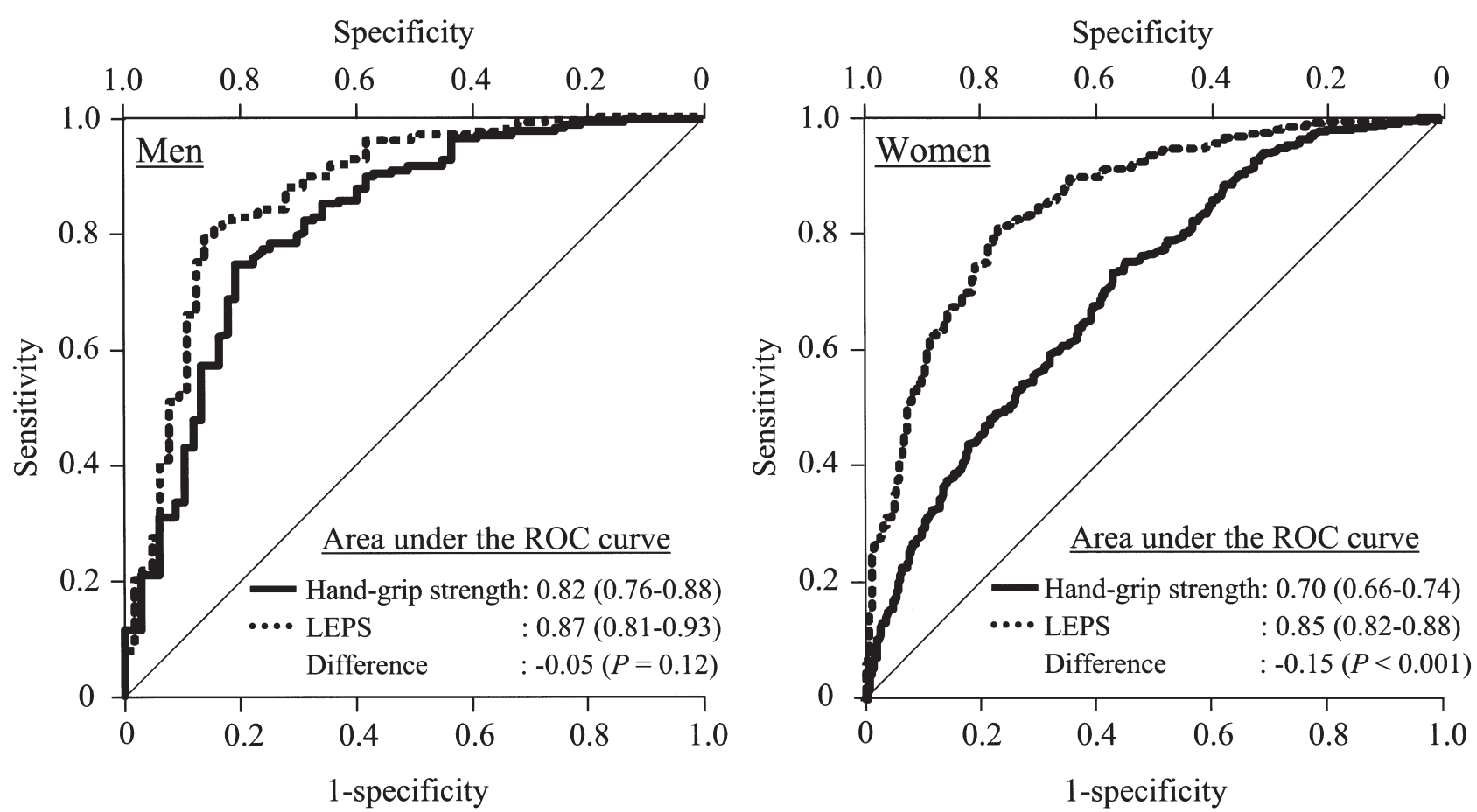

Fig 1. Receiver operating characteristic (ROC) curves plot for identifying mobility limitation (ML) according to hand-grip strength and lower extremity performance score (LEPS). 
Table 2. Optimal cut-off values of hand-grip strength and LEPS to distinguish ML

\begin{tabular}{lccc}
\hline & Cut-off value & sensitivity (\%) & specificity(\%) \\
\hline Men & & & \\
Hand-grip strength, kg & 31.0 & 75 & 81 \\
LEPS, point & 0.20 & 81 & 84 \\
Women & & & \\
Hand-grip strength, kg & 19.6 & 73 & 57 \\
LEPS, point & -0.01 & 81 & 77 \\
\hline
\end{tabular}

Notes: LEPS = lower extremity performance score; $\mathrm{ML}=$ mobility limitation

Table 3. Odds raito and 95\% confidence interval at cut-off value for hand-grip strength and LEPS for ML

\begin{tabular}{lcc}
\hline & OR at cut-off value & $\begin{array}{c}\text { Age adjusted OR } \\
\text { at cut-off value }\end{array}$ \\
\hline Men & $12.4(6.2-24.6)$ & $8.1(3.9-16.7)$ \\
$\quad$ Hand-grip strength & $18.2(9.0-36.7)$ & $12.9(6.2-26.8)$ \\
LEPS & $3.6(2.6-5.0)$ & $2.3(1.6-3.3)$ \\
Women & $10.1(7.0-14.4)$ & $6.7(4.6-9.8)$ \\
$\quad$ Hand-grip strength &
\end{tabular}

Notes: LEPS = lower extremity performance score; ML = mobility limitation; $\mathrm{OR}=$ Odds ratio

N. 考

察

\section{A. 握力による MLの識別力}

本研究は, フィールドテストの中で最も沉用性の 高い握力によるMLの識別可能性を検討した。識別 能を表わすAUCは，0.7から0.8であれば十分な識別 力であることを，0.8から0.9であれば優れた識別力 であることを，0.9以上であれば極めて優れた識別 力であることを示す ${ }^{26)}$. LEPSはMLに対して男女 とも優れた識別力を有していた。男性では，握力 とLEPSのAUCに有意差がなく，握力のみでLEPS と同等に MLの識別力を有することが示された。一 方，女性では握力が一定の識別力を有するものの， LEPSの識別力との間に著差がみられたこと，そし て最適なカットオフ值の特異度が低いことを勘案す ると，握力のみでMLを識別するには限界を有する と考えられる。

これまで，握力を用いてMLの識別を試みた研究
は, Sallinen et al. ${ }^{19)}$ の他に 1 編のみ報告されている. Lauretani et al. ${ }^{27)}$ は, イタリアの20〜102歳の男女 1030名を対象にサルコペニアの指標として等尺性膝 伸展筋力, 握力, 下肢筋パワー, 腓腹筋断面積を測 定し, 歩行速度 $0.8 \mathrm{~m} / \mathrm{s}$ 未満と $1 \mathrm{~km}$ 歩行の困難性に 対する識別力をそれぞれ検討している. Lauretani et al. ${ }^{27)}$ の対象者は，年齢層が幅広いものの肥満者 の割合が小さく, Sallinen et al. ${ }^{19)}$ の対象者に比べ ると日本人の特徵にやや近い集団であった。また， 本研究同様, 筋力を過小評価する可能性のある神経 性障害や認知障害を有する対象者を除外して分析し ている。歩行速度 $0.8 \mathrm{~m} / \mathrm{s}$ 未満に対する握力の AUC は，男女でそれぞれ0.90，0.79であり，1 km歩行 の困難性に対する握力の AUCは，男女でそれぞれ 0.83，0.75と，いずれも男性で高い識別力を有する という本研究と同様の結果が得られている.

本研究における握力の識別力の性差は, ORにも 反映されている（Table 3)，男性では，加齢に伴い 
下肢筋力と並行して上肢筋力も同様に低下寸る一方 で，女性では下肢筋力に比べて上肢筋力は低下しに くいことが横断研究 ${ }^{28)}$ と縦断研究 ${ }^{29)}$ のいずれにお いても示されている．特に男性の上肢筋力は女性よ りも急勾配で低下するため ${ }^{28)}$, 握力が虚弱過程の初 期段階であるMLを強く反映したのかもしれない. Lynch et al. ${ }^{28)}$ によると, 加齢に伴って下肢筋力は 男女とも同程度の割合で低下寸る。そのため, ML も男女で同様に出現すると仮定できるが，女性の握 力低下が下肢筋力の低下に伴わないことが女性で識 別力の低かった要因の 1 つとして考えられる.

しかし，女性において上肢筋力と下肢筋力の低下 様相が異なる点については, 必ずしもコンセンサス が得られていない30,31)。また, Lauretani et al. ${ }^{27)}$ の研究では, 女性においても MLに対する握力 (0.75) と膝伸展筋力（0.76）の識別力が同程度であった。 したがって, 上述した上肢筋力と下肢筋力の低下様 相の相違という要因が当てはまらない可能性もあ る。

特筆すべき特徵は, 握力（男性: 0.83 , 女性:0.75） と膝伸展筋力（男性：0.85, 女性：0.76）の識別力 が一貫して男性よりも女性で低いことである ${ }^{27)}$ 。先 行研究におけるこの結果は, 女性の移動能力に対す る筋力の寄与率が，男性よりも低いことを示唆する ものである。実際に，女性では男性よりも相対的な 筋量も少ないため ${ }^{32)}$, 女性の移動能力にはバラン ス能力や協調性（コーディネーション）など, 筋力 以外の要素の補完的な影響度が強くなると考えられ る. そのため, 本研究に扔いて, 女性のMLに対す る握力の識別力が男性に比べて顕著に低值を示した 可能性がある。一方, 本研究で用いた LEPSは, 下 肢筋力のみならず，バランスや協調性を含めた広範 なLEPを据えられるため ${ }^{11)}$, 女性のLEPSの識別力 が男性と同等に高值を示した可能性が考えられる。

以上を鑑みると, 男性では握力によってLEPと 同等に身体的虚弱化の段階を評価できるのかもしれ ない，女性では身体的虚弱化の段階を握力のみで評 価することは不十分である可能性が高く, 他の上 肢パフォーマンス (upper extremity performance: UEP）テストやLEPテストの併用から総合的に評 価していく必要があろう. Wennie Huang et al. ${ }^{33)}$ は, 高齢女性を対象とした縦断研究の中で, ADL 障害発生に対する上肢・下肢の機能低下との関連に
ついて更なる検討の必要性を示唆しており, 今後 $\mathrm{UEP} \cdot \mathrm{LEP}$ 低下と身体的虚弱段階との関係を性別 に検討することが求められる。

\section{B. カットオフ值の妥当性}

これまで示されたカットオフ值をみると, Lauretani et al. ${ }^{27)}$ は, 歩行速度 $0.8 \mathrm{~m} / \mathrm{s}$ 未満に対する握力 の最適なカットオフ值を男女でそれぞれ $30.3 \mathrm{~kg}$, $19.3 \mathrm{~kg}, 1 \mathrm{~km}$ 歩行の困難性に対するカットオフ值を それぞれ $32.8 \mathrm{~kg}, 20.5 \mathrm{~kg}$ （感度, 特異度いずれも不 記載）と示している. Kim et al. ${ }^{34)}$ は, 75歳以上の 本邦地域在住高齢女性306名を対象に, 障害の程度 を確認するためのパフォーマンステストについて検 討している。歩行および階段昇段動作ができない, または補助を要する場合を移動能力障害とし, 握力 の移動能力障害, ADL障害のカットオフ值をそれ ぞれ $19.5 \mathrm{~kg}$ （感度：66\%, 特異度：65\%)，16.3kg（感 度：69\%，特異度：66\%）と報告している。 Wennie Huang et al. の縦断研究 ${ }^{33)}$ では, 女性の ADL障害の カットオフ值が $16 \mathrm{~kg}$ （感度：59\%, 特異度 : 59\%) と報告されている，女性では，肥満者において握力 と脚筋力との関連が弱くなるものの ${ }^{35)}$, 体格 (BMI) が異なってもカットオフ值の精度は変わらない ${ }^{19)}$. したがって, 上述した先行研究の值を考慮すると, 測定姿勢の差異 ${ }^{21)}$ を踏まえたとしても本研究で得 られたMLのカットオフ值 $(19.6 \mathrm{~kg})$ は妥当な值と 考えられる. 厚生労働省介護予防継続的評価支援事 業のデータベースから作成された二次予防事業の対 象者（旧：特定高齢者）と要支援者の運動器関連指 標評価基準 ${ }^{36)}$ に照らし合わせると，男性のカットオ フ值も概ね妥当と考えられ, 感度, 特異度も良好で あった。しかし, 比較可能な先行研究が極めて少な い上に, 体格の影響を受けやすいことが示唆されて いる ${ }^{19)}$. 本研究では, 肥満者数が少なかったため体 格を考慮せず解析しているが, 男性においては今後 対象者を増やし，体格ごとにカットオフ值を求める ことの必要性を検討したい.

\section{C. 本研究の限界と課題}

本研究の対象者は, 茨城県およびその近隣の県 (千 葉県, 福島県) に在住する高齢者である。また, デ イサービスセンターでの測定もおこなっているもの の, 大多数が体力測定会に参加した高齢者であるこ 
とを考慮すると, 相対的に体力レベルの高い集団で あった可能性がある。

Table 3 において, 年齢調整後のORが大きく変 動したことを踏まえると，MLには年齢の影響も大 きいといえる，ML群では年齢に性差がみられな かったが $(P=0.56)$ ，男性ではML群がほぼ平均寿 命に相当する年齢であったのに対し，女性では ML 群の年齢が平均寿命よりも10歳程若かった。識別力 の性差を厳密に検討するに当たっては，男女の平均 余命に対する年齢差を考慮することが必要かもしれ ない。 ただし，個人差が大きいため，このような年 齢の整合は極めて難しい，また，身体的自立を長期 にわたって維持するには，年齢に関係なく，一定の 能力を維持していることが重要である。これらの観 点から, 本研究では, 平均余命までをも考慮した年 齢整合の必要性はそしいと考えた。

自己報告による機能障害の評価は，対象者本人の 日常的な生活状況を忠実に反映するため妥当な方法 として用いられているものの，男性では障害を過小 に報告し，女性では過大に報告する可能性が示唆さ れている ${ }^{37)}$ ，本研究結果を他の研究に適用する際 は，上述したこれらの点を踏まえておく必要がある だろう。

カットオフ值そのものは妥当な值と考えている が，感度と特異度が表わす通り，完全にMLを識別 可能なものではない，本研究では，解析に際し十分 な対象者数を用いることができたが，横断研究であ るため，握力の低下がMLにつながるという因果関 係を踏まえた検討まで至らなかった。また，握力は 疫学的な指標として極めて有用だが, 運動介入では 必ずしも握力の向上のみを目的とするわけではな く，短期間での変化が見込める項目ではない，した がって，介入によるMLの変化を反映しない可能性 がある。これらも含めて, カットオフ值の妥当性は, 縦断研究によってさらに検討を重ねる余地がある。 それとともに，感度および特異度が顕著に高值でな い限り，カットオフ值を健康支援現場へ適用するこ とが実用的か否かについても検討すべきであろう。

以上のような限界と課題を有するものの，約 1000 名の本邦地域在住高齢者を対象に，握力による $\mathrm{ML}$ の識別可能性と基準值を提案した点で, 本研究の意 義は大きい. LEPテストはMLを妥当に評価できる ものの，対象者が虚弱であるほど完遂できない者も
多く34，転倒などの危険を少なからず伴う。握力 測定は簡便性，安全性，汎用性が非常に高いことか ら，研究フィールドや健康支援現場においてMLの 指標としても有効活用が可能と考えられる.

\section{V. 結語}

男性では，握力によって LEP と同等にMLを識別 することが可能である。一方，女性では握力が ML に対して一定の識別力を有しているものの，LEPS の識別力との間に著差があり，身体的虚弱段階を評 価するためには握力とLEPテストを併用していく 必要性が示唆された。

\section{謝 辞}

本研究は, 文部科学省科学研究費補助金研究事業：基 盤研究 A「要介護化予防を目的とした中・高齢期の身体 機能改善のための包括的指針づくり」(代表:田中喜代次) の支援を受けて扮こなったものである。本研究は，研究 にご参加いただいた対象者をはじめ，各自治体抒よび施 設職員の方々, 筑波大学田中研究室の大学院生の協力に よって遂行できた。ここに記して感謝の意を表わす。

\section{文献}

1) Guralnik JM, LaCroix AZ, Abbott RD, Berkman LF, Satterfield S, Evans DA, Wallace RB. Maintaining mobility in late life. I. Demographic characteristics and chronic conditions. Am J Epidemiol, 137: 845857, 1993.

2) Fried LP, Guralnik JM. Disability in older adults: evidence regarding significance, etiology, and risk. $J$ Am Geriatr Soc, 45 (1): 92-100, 1997.

3) Jylha M, Guralnik JM, Balfour J, Fried LP. Walking difficulty, walking speed, and age as predictors of self-rated health: the women's health and aging study. J Gerontol A Biol Sci Med Sci, 56: M609-617, 2001.

4) Manty M, Heinonen A, Viljanen A, Pajala S, Koskenvuo M, Kaprio J, Rantanen T. Self-reported preclinical mobility limitation and fall history as predictors of future falls in older women: prospective cohort study. Osteoporos Int, 21: 689-693, 2010.

5) Volpato S, Cavalieri M, Sioulis F, Guerra G, Maraldi C, Zuliani G, Fellin R, Guralnik JM. Predictive value of the short physical performance battery following hospitalization in older patients. $J$ Gerontol A Biol Sci Med Sci, 66: 89-96, 2011.

6) Woo J, Ho SC, Yu ALM. Walking speed and stride length predicts 36 months dependency, mortality, and institutionalization in Chinese aged 70 and older. 
J Am Geriatr Soc, 47: 1257-1260, 1999.

7) Guralnik JM, Ferrucci L, Pieper CF, Leveille SG, Markides KS, Ostir GV, Studenski S, Berkman LF, Wallace RB. Lower extremity function and subsequent disability: Consistency across studies, predictive models, and value of gait speed alone compared with the short physical performance battery. $J$ Gerontol A Biol Sci Med Sci, 55A: M221-M231, 2000.

8) Guralnik JM, Ferrucci L, Balfour JL, Volpato S, Di lorio A. Progressive versus catastrophic loss of the ability to walk: implications for the prevention of mobility loss. J Gerontol A Biol Sci Med Sci, 49: 1463-1470, 2001.

9) Kim MJ, Yabushita N, Kim MK, Nemoto M, Seino S, Tanaka K. Mobility performance tests for discriminating high risk of frailty in community-dwelling older women. Arch Gerontol Geriatr, 51: 192-198, 2010.

10) Kim MJ, Seino S, Kim MK, Yabushita N, Okura T, Okuno J, Tanaka K. Validation of lower extremity performance tests for determining the mobility limitation levels in community-dwelling older women. Aging Clin Exp Res, 21: 437-444, 2009.

11）清野諭, 藪下典子, 金美芝, 根本みゆき, 松尾知明, 深作貴子, 奥野純子, 大藏倫博, 田中喜代次. 特定高 齢者の体力を把握するためのテストバッテリ．日本 公衆衛生雑誌, 56: 724-736, 2009.

12) Visser M, Goodpaster BH, Kritchevsky SB, Newman AB, Nevitt M, Rubin SM, Simonsick EM, Harris TB. Muscle mass, muscle strength, and muscle fat infiltration as predictors of incident mobility limitations in well-functioning older persons. $J$ Gerontol A Biol Sci Med Sci, 60: 324-333, 2005.

13) Rantanen T, Era P, Kauppinen M, Heikkinen E. Maximal isometric muscle strength and socioeconomic status, health, and physical activity in 75-year-old persons. J Aging Phys Act, 2: 206-220, 1994.

14) Cooper R, Kuh D, Cooper C, Gale CR, Lawlor DA, Matthews F, Hardy R; the FALCon and HALCyon study teams. Objective measures of physical capability and subsequent health: a systematic review. Age Ageing, 40: 14-23, 2011.

15) Syddall H, Cooper C, Martin ZF, Briggs R, Sayer AA. Is grip strength a useful single marker of frailty? Age Ageing, 32: 650-656, 2003.

16) Sayer AA, Syddall HE, Martin HJ, Dennison EM, Roberts HC, Cooper C. Is grip strength associated with health-related quality of life? Findings from the Hertfordshire cohort study. Age Ageing, 35: 409-415, 2006.

17) Al Snih S, Markides KS, Ottenbacher KJ, Raji MA. Hand grip strength and incident ADL disability in elderly Mexican Americans over a seven-year pe- riod. Aging Clin Exp Res, 16: 481-486, 2004.

18) Rantanen T, Volpato S, Ferrucci L, Heikkinen E, Fried LP, Guralnik JM. Handgrip strength and cause-specific and total mortality in older disabled women: exploring the mechanism. J Am Geriatr Soc, 51: 636-641, 2003.

19) Sallinen J, Stenholm S, Rantanen T, Heliovaara M, Sainio P, Koskinen S. Hand-grip strength cut points to screen older persons at risk for mobility limitation. J Am Geriatr Soc, 58: 1721-1726, 2010.

20) Fess FE. Grip strength. In: Casanova JS clinical assessment recommendations, Chicago, IL: American society of hand therapists, 41-45, 1992.

21）渡邊忠良, 金内ゆみ子, 井田英雄. 握力測定姿勢 - 肢位 の違いによる握力值と再現性の検討. 臨床整形外科, 40, 665-671, 2005.

22）福原俊一, 鈴鴨よしみ. SF-36v2 日本語版マニュアル, NPO 健康医療評価研究機構, 京都, 89-97, 2004.

23) Nakamura E, Miyao K, Oseki T. Assessment of biological age by principal component analysis. Mech Ageing Dev, 46: 1-18, 1988.

24) DeLong ER, DeLong DM, Clarke-Pearson DL. Comparing the areas under two or more correlated receiver operationg characteristic curves: a nonparametric approach. Biometrics, 44: 837-845, 1988.

25) Perkins NJ, Schisterman EF. The inconsistency of 'optimal' cutpoints obtained using two criteria based on the receiver operating characteristics curve. $A m$ J Epidemiol, 163: 670-675, 2006.

26) Hosmer DW, Lemeshow S. Applied logistic regression, $2^{\text {nd }}$ ed. New York: John Wiley \& Sons, Inc., 2000.

27) Lauretani F, Russo CR, Bandinelli S, Bartali B, Cavazzini C, Dilorio A, Corsi AM, Rantanen T, Guralnik JM, Ferrucci L. Age-associated changes in skeletal muscles and their effect on mobility: an operational diagnosis of sarcopenia. J Appl Physiol, 95: 1851-1860, 2003.

28) Lynch NA, Metter EJ, Lindle RS, Fozard JL, Tobin JD, Roy TA, Fleg JL, Hurley BF. Muscle quality. I. Age-associated differences between arm and leg muscle groups. J Appl Physiol, 86: 188-194, 1999.

29) Hughes VA, Frontera WR, Wood M, Evans WJ, Dallal GE, Roubenoff R, Fiatarone Singh MA. Longitudinal muscle strength changes in older adults: influence of muscle mass, physical activity, and health. $J$ Gerontol A Biol Sci Med Sci, 56: B209-B217, 2001.

30) Rantanen T, Era P, Heikkinen E. Physical activity and the changes in maximal isometric strength in men and women from the age of 75 to 80 years. $J$ Am Geriatr Soc, 45: 1439-1445, 1997.

31) Bassey EJ. Longitudinal changes in selected physical capabilities: Muscle strength, flexibility and body size. Age Ageing; 27: 12-16, 1998. 
32) Janssen I, Heymsfield SB, Wang ZM, Ross R. Skeletal muscle mass and distribution in 468 men and women aged 18-88 yr. J Appl Physiol, 89: 81-88, 2000.

33) Wennie Huang WN, Perera S, VanSwearingen J, Studenski S. Performance measures predict onset of activity of daily living difficulty in communitydwelling older adults. J Am Geriatr Soc, 58: 844-852, 2010.

34) Kim MJ, Yabushita N, Kim MK Matsuo M, Okuno J, Tanaka K. Alternative items for identifying hierarchical levels of physical disability by using physical performance tests in women aged 75 years and older. Geriatr Gerontol Int, 10: 302-310, 2010.
35) Hulens M, Vansant G, Lysens R, Claessens AL, Muls E, Brumagne S. Study of differences in peripheral muscle strength of lean versus obese women: an allometric approach. Int J Obes Relat Metab Disord, 25: 676-681, 2001.

36）大㴊修一, 小島基永, 三木明子, 伊藤和彦, 新井武志, 辻一郎, 大久保一郎, 大原里子, 杉山みち子, 鈴木隆雄, 曽根稔雅, 安村誠司. 介護予防対象者の運動器関連指 標評価基準. 日本公衆衛生雑誌, 57: 988-995, 2010.

37) Merrill SS, Seeman TE, Kasl SV, Berkman LF. Gender differences in the comparison of self-reported disability and performance measures. $J$ Gerontol A Biol Sci Med Sci, 52A: M19-M26, 1997. 